\title{
Analysis of Patients Complaints Reviewed from Human Resources Factors, Health and Private Facilities Services
}

\author{
Danang Sasongko, Sentot Imam \\ Suprapto, Indasah \\ Caruban Hospital, Madiun, \\ Indonesia \\ Email: \\ danang@gmail.com
}

Received : March 12, 2019

Accepted : October 13, 2019

Published : November 26, 2019

\begin{abstract}
Services provided by hospitals sometimes cause dissatisfaction, dissatisfaction can be conveyed through patient complaints, patient complaints can be caused by factors of human resources, health services or available facilities. The purpose of this study was to determine the factors that influence patient complaints in the Inpatient Room of the Caruban Hospital Pavilion in Madiun Regency.

In this study, researchers used an observational research design with a Cross Sectional approach. The sample in this study amounted to 80 respondents. Purposive sampling technique. The research instrument uses a questionnaire with ordinal regression statistical test with $\alpha=0.05$.

Most respondents $57.9 \%$ (113 people) stated that Human Resources in the Inpatient Room were good. Most respondents $53.8 \%$ (105 people) stated that health services in the Inpatient Room were good. Almost half of the respondents 46.2\% (90 people) stated that the factors of facilities and infrastructure in the Inpatient Room were good. The majority of respondents $53.8 \%$ (103 people) showed patient complaints in the low inpatient room. There was an influence of Human Resources with complaints from patients in the Inpatient Hospital of Caruban Hospital in Madiun Regency, $p=0040$. there was no influence of health services with complaints of patients in the Inpatient Room of the Caruban Hospital of Madiun District, $p=0.193$. There is an influence of facilities and infrastructure with patient complaints in the Inpatient Care Unit of Caruban Hospital in Madiun Regency, $\mathrm{p}=0.048$.

The most influential factor on patient complaints in the Inpatient Pavilion is a factor of human resources and facilities and infrastructure factors because with good resources the service will be excellent supported by the existing facilities and infrastructure.
\end{abstract}

Keywords: Patient complaints, Human Resources, Health Services, facilities and infrastructure 


\section{INTRODUCTION}

The era of the development of science, especially information technology, which is very rapid nowadays, has implications for the ease with which people convey information and complaints to the public service problems they receive. Complaints are statements of dissatisfaction in any form (body language, oral or written) about services, actions or shortcomings carried out by service delivery organizations or implementers of public services that affect or are perceived by the service user community (Permenpan No. 13 of 2009). According to Griffin (2013), in his research found that no one always feels satisfied, especially the relationship between the company and its customers in a long time. Therefore complaints are things that cannot be avoided in a public service including health services.

Submission of complaints from the public, especially consumers according to Law No. 8 of 1999 concerning Consumer Protection article 4 (d) stated that consumers (customers) have the right to be heard opinions and complaints about goods and / or services used. According to Paterson (2013) also states that customer complaints are usually a last resort after frustration trying other ways without results, where complaints might trigger fierce reactions, ranging from embarrassment to anger. Because the patient as an external customer of the hospital not only wants healing from the illness which is the outcome of the service, but also feels and evaluates how he is treated in the service process. So from that service must be focused on the customer by paying attention to the needs (needs), expectations (expectation), and the assessment of the benefits (value) of the customer as a requirement proposed by him. Efforts to improve quality and performance need to refer to the customer trilogy requirements. Fulfillment of customer needs, expectations, and judgments on the performance and benefits of the product or service provided will result in customer satisfaction (Koentjoro, 2011).

The study conducted by Giugliani et al. (2009) at the University Hospital in France, found a significant increase in the number of patient complaints regarding medical issues, namely by $47 \%$ in 1998 to $73 \%$ in 2004. The increase in complaints of these patients was $66 \%$ because they were motivated by patient perceptions about medical errors. Which is the main reason for the complaints of these patients are: the existence of errors or delays in diagnosis or management, complications of treatment or surgery, disability and adverse events. According to Moghadam et al. (2010) some patient complaints that occurred related to admission procedures were $34.7 \%$, followed by communication $34.1 \%$, waiting time $13.8 \%$, and delay in action $6.8 \%$, ignoring the clinical standard of care $4.1 \%$.

A preliminary study at the Caruban District Hospital in Madiun found the number of patient visits which continued to increase in recent years which correlated with the number of patients who complained. According to the data in the Public Relations and Marketing installation and in the service units, the number of patients complaining about the services at the Caruban Hospital in Madiun Regency.

The number of patient complaints according to information from Public Relations \& Marketing officers are many that are not recorded because they are mild and are immediately resolved in service units. Of the 80 complaints over the last three years (figure 1.1) there was an absolute increase of 19 cases in 2010, 23 cases in 2011, and 38 cases in 2012. When viewed from the percentage of patients complaints compared to the total patient visits each year ( table 1.2), tends to increase, namely: 2015 as much as 0.181 percent, in 2016 reached 0.193 percent, and in 2017 as much as 0.288 percent, although the BOR from 2010 to 2012 decreased.

Of the 80 cases of complaints over the past three years, it was identified that the way patients or families of patients convey hospital service complaints through various facilities, for example by coming directly to service units or public relations and marketing installations, through mass media (newspapers), through call centers. Various causes that can cause complaints include: officer communication problems, page waiting times, unclear procedures and information, service tariffs or fees and others such as: hospital location problems, security and others.

Service is performance to achieve satisfaction and bonding. The measurement of the quality of services in hospitals cannot be equated with measurements and descriptions of the quality of goods due to differences in the characteristics of both (Sudarto, 2010). The five main factors that determine the quality of services. The five main factors are reliability, responsiveness, confidence, empathy and physical form. These five factors are displayed by the service provider beyond what is expected by consumers so that satisfaction arises in consumers. Conversely, if the service quality provided by service providers is far below expectations, then consumers will feel dissatisfied and there will be many complaints (Nugroho, 2010). In order to improve the quality of services there must be an effort to find 
out the diverse expectations and needs of patients. Especially patients treated in the Pavilion care room, economically they are able to pay automatically they expect maximum service from the Hospital. This is very important to determine the hospital marketing strategy that is oriented to patient satisfaction. Patients who are satisfied with the service they receive will participate in marketing word of mouth and create relationship marketing. The purpose of this study was to determine the factors that influence patient complaints in the Inpatient Room of Caruban Hospital, Madiun Regency.

\section{MATERIALS AND METHODS}

In this study, researchers used an observational research design with a Cross Sectional approach. The sample in this study amounted to 80 respondents. Purposive sampling technique. The research instrument uses a questionnaire with ordinal regression statistical test with $\alpha=0.05$.

\section{RESULT}

\section{Subject Characteristics}

Table 1. The characteristics of the respondents in this study included age, sex, education, occupation, disease diagnosis, length of care, payment, human resources, health services, facilities and patient complaints.

\begin{tabular}{|c|c|c|c|}
\hline No & Characteristics & $\Sigma \mathbf{N}$ & $\Sigma \%$ \\
\hline \multirow[t]{5}{*}{1} & Age (year) & & \\
\hline & $<20$ & 39 & 20 \\
\hline & $20-35$ & 93 & 48 \\
\hline & $36-55$ & 35 & 18 \\
\hline & $>55$ & 27 & 14 \\
\hline \multirow[t]{3}{*}{2} & Gender & & \\
\hline & Man & 92 & 47 \\
\hline & Female & 104 & 53 \\
\hline \multirow[t]{5}{*}{3} & Education & & \\
\hline & Elementary school & 23 & 12 \\
\hline & Junior high school & 37 & 19 \\
\hline & Senior high school & 76 & 39 \\
\hline & University & 59 & 30 \\
\hline \multirow[t]{5}{*}{4} & Occupation & & \\
\hline & Housewives / not working & 31 & 16 \\
\hline & Private & 51 & 26 \\
\hline & Entrepreneur & 62 & 32 \\
\hline & Civil servants & 51 & 26 \\
\hline \multirow[t]{6}{*}{5} & Disease diagnosis & & \\
\hline & Heart & 64 & 34 \\
\hline & Lungs & 39 & 20 \\
\hline & Internal disease & 43 & 22 \\
\hline & Surgery & 33 & 17 \\
\hline & Urology & 4 & 2 \\
\hline \multirow[t]{4}{*}{6} & length of care (day) & & \\
\hline & $3-4$ & 92 & 47 \\
\hline & $5-7$ & 80 & 41 \\
\hline & $>7$ & 23 & 12 \\
\hline \multirow[t]{4}{*}{7} & Payment & & \\
\hline & General & 33 & 17 \\
\hline & BPJS non PBI & 111 & 57 \\
\hline & BPJS PBI & 51 & 26 \\
\hline \multirow[t]{4}{*}{8} & Human resources & & \\
\hline & Less & 21 & 10,8 \\
\hline & Enough & 61 & 31,3 \\
\hline & Good & 113 & 57,9 \\
\hline
\end{tabular}




\begin{tabular}{llll}
9 & Health service & & \\
& Less & 22 & 11,3 \\
& Enough & 68 & 34,9 \\
& Good & 105 & 53,8 \\
\hline 10 & Facilities & & \\
& Less & 25 & 12,8 \\
& Enough & 80 & 41 \\
& Good & 90 & 46,2 \\
\hline 11 & Patient complants & & \\
& High & 21 & 10,8 \\
& Middle & 71 & 36,4 \\
& Low & 103 & 52,8 \\
\hline & Total & $\mathbf{1 9 5}$ & $\mathbf{1 0 0}$ \\
\hline & & &
\end{tabular}

\section{STATISTICAL TEST RESULTS}

Table 2. Ordinal regression statistical test results analyze patient complaints in terms of the factors of Human Resources, health services and infrastructure in the Inpatient Room of the Pavilion of Caruban Hospital, Madiun District, September 1-30 2018

\begin{tabular}{lc}
\hline \multicolumn{1}{c}{ regresi ordinal analysis } & Signifikansi \\
\hline Human Resources with Patient Complaints & 0,040 \\
Health Services with patient complaints & 0,193 \\
Facilities and infrastructure with patient complaints & 0,048 \\
\hline
\end{tabular}

From the results of statistical tests on Human Resources with complaints obtained a significance value is $p=0.040$ which means smaller than the value of $\alpha=0.05(p=0.040<\alpha=0.05)$ means that Ho rejects, the conclusion is the influence of Human Resources with patient complaints in the Inpatient Room of Caruban Hospital, Madiun Regency

\section{DISCUSSION}

\section{Factors of Human Resources in the Inpatient Room of Caruban Hospital, Madiun Regency}

The results showed that most respondents 57.9\% (113 people) stated that Human Resources in the Inpatient Room of Caruban Hospital in Madiun District were good and almost half of the respondents $(32.5 \%)$ stated that human resource services were classified as sufficient.

The resources in this study are the ability of health care doctors and nurses to provide services directly to patients, whether the existing resources have reliability in providing services. Reliability factor according to Sangadji (2013) is the ability of service providers in providing services quickly, precisely, accurately and satisfactorily. Whereas according to Muninanjaya (2011) the reliability of service providers with the suitability of services with plans, reliability in delivering initial services, timeliness in providing services, and accuracy of handling. Ramez's research (2012) shows that the reliability of nurses in providing nursing services has a significant relationship with patient satisfaction.

From the description above, the researcher argues that good resource services will reduce patient complaints, even the smallest service resources will become the patient's attention so that as a hospital staff must provide the patient with maximum care so that patients are satisfied and the patient's complaint level is low.

\section{Health service factors in the Inpatient Room of Caruban Hospital, Madiun Regency}

The results showed that the majority of respondents 53.8\% (105 people) stated that the health services in the Inpatient Room of Caruban Hospital in Madiun District were good. Hospitals are required to provide quality services in accordance with established standards or procedures and can be reached by all levels of society. Standard is the ideal state or the highest and perfect level of achievement that is used as a minimum acceptance limit (Aditamar, 2013). The results of this study indicate that the 
health services available in the Inpatient Room of Caruban Hospital, Madiun Regency, according to respondents, are good.

According to Paterson (2013) also states that customer complaints are usually a last resort after frustration trying other ways without results, where complaints might trigger fierce reactions, ranging from embarrassment to anger. Because the patient as an external customer of the hospital not only wants healing from the illness which is the outcome of the service, but also feels and evaluates how he is treated in the service process. So from that service must be focused on the customer by paying attention to the needs (needs), expectations (expectation), and the assessment of the benefits (value) of the customer as a requirement proposed by him. Efforts to improve quality and performance need to refer to the customer trilogy requirements. Fulfillment of customer needs, expectations, and ratings of the performance and benefits of the product or service provided will result in customer satisfaction.

From the description above, the researcher argues that the health services in the Inpatient Room of Caruban Hospital in Kabupaten Madiun are good but in overcoming the patient's complaints there are no clear references. The alignment of health services to patients in providing their expected needs is not easy, when patients come with acute illnesses and must be helped or elective services (planned) will experience disappointment if they come to the hospital to meet with registration officers not to get a place sleep (nursing room), this is often faced daily in the service of patients in the hospital.

\section{Factors of facilities and infrastructure in the Inpatient Room of Caruban Hospital, Madiun Regency}

The results showed that almost half of the respondents $46.2 \%$ (90 people) stated that the factors of facilities and infrastructure in the Inpatient Room of Caruban Hospital in Madiun District were good. Facilities of health service infrastructure can be defined as a collaborative process of utilizing all health facilities and infrastructure effectively and efficiently to provide services professionally in the field of facilities and infrastructure in the process of health services that are effective and efficient as well (Muhammad, 2010). Completeness of good infrastructure is a very important thing in creating customer satisfaction. Febriani (2012) which states that service quality is harder to evaluate compared to the quality of goods. With good infrastructure, the utilization of beds will also increase, because patients feel their health will be guaranteed by complete infrastructure.

From the description above, the researcher argues that the facilities and infrastructure in the Hospital are quite good, but there are some that must be improved according to the statement of the respondents, including the cleanliness of the bathroom and also medical equipment facilities also need to be improved. Consumers will decide to use or take advantage of the health service suggestions based on the behavior of the factors that influence it. Hospital hygiene and sanitation programs require not a small amount of money, so often the director or hospital management disagrees with the reasons for budget constraints. Though this antimicrobial resistance control program actually provides many benefits, for example reducing the risk of surgery, chemotherapy, and long-term benefits to prevent the occurrence of total resistance or the return of the medical world to the era before antibiotics. In addition to hand hygiene which is the main key, safety, cleanliness of surfaces all the time, easy access, heating, ventilation and air conditioning, and water management that are used hold an important role in protecting officers and patients.

\section{Patient complaints in the Inpatient Room of Caruban Hospital, Madiun Regency}

The results showed that the majority of respondents 53.8\% (103 people) showed that patients' complaints in the Inpatient Room of Caruban Hospital in Madiun District were low, as many as 36.4\% were moderate and there were $10.8 \%$ patients who showed high patient complaints.

Complaints or service complaints are expressions of feelings of dissatisfaction with service standards, actions or lack of service provider actions that affect customers. The process starts from consumers feeling dissatisfied after receiving services or making transactions. In providing health services in hospitals, there are no complaints that occur between patients and hospitals. Complaint is a result of a situation where the desire or will is different or opposite between the patient and the hospital, so that both are interrupted. For this reason complaints need to be resolved properly so that they do not extend too far and the subject matter (Tjiptono, 2014).

For this reason, a guide is needed to handle complaints in overcoming them so that everything can be overcome. Patients who feel dissatisfied will take a position to complain to the hospital for their 
complaints, and it is the duty of the hospital to answer and explain complaints and the patient's side. In every complaint given, by the patient to the hospital, it is always responded to well and resolved quickly, this is indeed done so that there is no serious conflict with the patient (Tjiptono, 2014).

From the description above, the researcher argues that the patient's complaints in the Inpatient Room of Caruban Hospital, Madiun District are low, but there are still respondents who show high complaints, this is caused by many factors including incomplete equipment, dissatisfaction with the explanation of doctors or nurses or distance from the pharmacy with a far enough treatment room. All complaints above are expected to be able to be overcome by management with effective complaint management. Effective management of complaint handling requires clear and well-structured procedures to solve problems and be supported by adequate resources and infrastructure to achieve satisfactory work performance.

\section{The most influential factor in patient complaints in the Inpatient Room of Caruban Hospital, Madiun Regency}

From the results of statistical tests on Human Resources with complaints obtained a significance value is $p=0.040$ which means smaller than the value of $\alpha=0.05(p=0.040<\alpha=0.05)$ means that Ho rejects, the conclusion is the influence of Human Resources with patient complaints in the Inpatient Room of Caruban Hospital, Madiun Regency.

The hospital was declared successful, not only on the service that was seeded, but also the attitude and service of human resources were the elements that influenced the services produced to patients. If these elements are ignored, in a short time, the hospital will lose many patients who are shunned by prospective patients. Patients will switch to other hospitals that meet patient expectations, because patients are valuable assets in developing the hospital industry (Anjaryani, 2009). This shows that there is a correspondence between the facts and the theory that human resources have an effect on patient complaints because with the patient's attention to the available human resources, there are fewer patient complaints.

From the results of statistical tests on health services with complaints obtained a significance value is $p=0.193$ which means greater than the value of $\alpha=0.05(p=0.193>\alpha=0.05)$ means that accept Ho, the conclusion there is no influence of health services with patient complaints in Inpatient Room of Caruban Hospital, Madiun Regency.

From the results of statistical tests on the facilities and infrastructure with complaints obtained a significance value is $p=0.048$ which means smaller than the value of $\alpha=0.05(p=0.048<\alpha=0.05)$ means that Ho rejects, the conclusion is the influence of facilities and infrastructure with patient complaints in the Inpatient Room of Caruban Hospital, Madiun Regency.

Completeness of good infrastructure is a very important thing in creating customer satisfaction. Febriani (2012) which states that service quality is harder to evaluate compared to the quality of goods. With good infrastructure, the utilization of beds will also increase, because patients feel their health will be guaranteed by complete infrastructure.

From the description above, the researcher argues that the most influential factor on patient complaints in the Inpatient Room is the factor of human resources and the factors of facilities and infrastructure because with good resources, the service will be prime supported by existing facilities and infrastructure. Hospitals are not only curative (healing), but also recovery (rehabilitative). Both are carried out in an integrated manner through health promotion efforts (promotive) and prevention (preventive). Thus, the target of RS health services is not only for individual patients, but also develops for families of patients and the general public. The focus of attention is indeed patients who come or are treated as individuals and part of the family. On the basis of such an attitude, health services in hospitals are complete health services (comprehensive and holistic)

\section{CONCLUSION}

There is the influence of Human Resources with patient complaints in the Inpatient Room of Caruban District Hospital, Madiun District, $p=0040$. There is no influence of health services with patient complaints in the Inpatient Room of Caruban Hospital, Madiun District, $p=0.193$. There are influences of facilities and infrastructure with patient complaints in the Inpatient Room of Caruban Hospital, Madiun Regency, $\mathrm{p}=0.048$. 


\section{REFERENCES}

Achmadi, Abu dan Narbuko Cholid. 2014. Metodologi Penelitian. Jakarta: Bumi. Aksara.

Aditama, 2015. Tiga aspek penilaian mutu pelayanan. http://mutupelayanan kesehatan.net/index.php/component/content/article/19-headline/1194-tiga-aspek-penilaianmutu-pelayanan. Diakses pada tanggal 11 November 2017.

Azwar, 2016. Penyusunan Skala Psikologi. Jakarta: Pustaka Pelajar.

Budiastuti, 2017. Kepuasan Pasien Terhadap Pelayanan Rumah Sakit. dari http://www.kepuasanpasien- terhadap--pelayanan- rumahsakit<Psikologi KlinisPerkembangandanSosial.htm. Diakses pada 19 November 2017.

Burhanudin, 2016. Strategi Kebijakan Moneter dalam Mendorong. Pertumbuhan Ekonomi yang Berkelanjutan. Bandung: Universitas. Padjajaran.

Depkes RI, 2015. Buku Petunjuk Pengisian, Pengolahan,dan Penyajian Data Rumah Sakit.Jakarta:Depkes RI.

Edvardsson, 2014. The effects of satisfaction and loyality on profits and growth : products versus services", Total Quality Managemen, Vol. 11.

Gerson, 2014. Mengukur Kepuasan Pelanggan, PPM, Jakarta.

Giugliani et al. 2015, There a contribution of a law regarding patients' rights. The Journal of Humanistic.

Griffin, Moorhead. 2016. Perilaku Organisasi (manajemen sumber daya manusia dan organisasi). Edisi 9. Salemba empat ; Jakarta

Hafizurrachman, 2014. Pengukuran Kepuasan Suatu Institusi Kesehatan.Majalah. Kedokteran Indonesia.

Hamdani, 2016. Manajemen Pemasaran jasa Edisi kedua. Penerbit Salemba Empat: Jakarta.

Heriandi, 2014. Perilaku dan Manajemen Organisasi. Jakarta: Erlangga

Herianto 2015. Mengelola Konflik di dalam Organisasi. Jurnal Anima

Hidayat, 2017. Riset Keperawatan dan Teknik Penu lisan Ilmiah. Salemba Medika: Edisi 2

Kepmenkes RI 2015. Keputusan Menteri Kesehatan No. 129/Menkes/SK/II/ 2008 Tentang SPM RS

Koentjoro, 2018. Regulasi Kesehatan di Indonesia.Yogyakarta: CV Andi

Kotler, Philip and Kevin Lane Keller. 2014. Marketing Management 13. New Jersey.

Lovelock.C dan Lauren K.Wright. 2015. Manajemen Pemasaran Jasa, Alih bahasa. Agus Widyantoro, Cetakan Kedua, Jakarta; PT. INDEKS.

Moghadam et al. 2015. Effect of The Social Responsibility on Earnings Response. Coefficient. World of Sciences Journal Vol.1

Nasution, 2015. Manajemen Mutu Terpadu.2015. Bogor. Ghalia Indonesia

Notoadmodjo, 2016. Metodologi Penelitian Kesehatan. Jakarta : Rineka Cipta

Nugroho, 2015. Kesehatan Wanita, Gender dan Permasalahannya. Yogyakarta : Nuha Medika.

Nurachmah, 2015 Asuhan Keperawatan Bermutu Di Rumah Sakit ; Jakarta : EGC

Paterson, 2014. The Preparation Of Humanistic. Teachers For Next Century Schools. Department of Counseling and. Specialized Educational Development. The Journal of Humanistic

Patria Jati, 2014. Beberapa Konsep Dasar tentang Manajemen Rumah Sakit. Prasetijo, Jakarta: PT Gramedia Pustaka Utama

Rekam Medik 2017. Catatan medik RSUD Caruban Kabupaten Madiun tahun 2017

Rusadi, 2014. Kajian Media Isu Ideologis Dalam Perspektif, Teori, dan.Metode. Jakarta : Rajawali Pers

Sabarguna, 2014. Rekam Medis Terkomputerisasi. Jakarta: Penerbit Universitas Indonesia

Soeharto A. Majid, 2015. Customer Service Dalam Bisnis Jasa. Transportasi

Sudarto, 2014. Hukum dan Perkembangan Masyarakat, Sinar baru, Bandung

Sugiono, 2016. Metode Penelitian Kuantitatif, Kualitatif dan R\&D. Bandung: Afabeta

Supranto, 2014. Statistik Teori dan Aplikasi, Erlangga, Jakarta

Suryawati, 2016. Sosiologi 1. Jakarta : Erlangga

Tjiptono, 2014. Pemasaran Jasa. Andi: Yogyakarta

YLKI 2015. Yayasan Lembaga Konsumen Indonesia Struktur Organisasi YLKI, Jakarta, ARTIKEL 